14. У Раді Свропи наголошують на важливості участі переселенців у місцевих вибоpax. URL: https://www.ukrinform.ua/rubric-regions/2649271-u-radi-evropi-nagolosuutna-vazlivosti-ucasti-pereselenciv-u-miscevih-viborah.html

15. URL: http://www.reyestr.court.gov.ua/Review/75544764

16. Про свободу пересування та вільний вибір місця проживання : Закону України № 1382-IV від 11.2.2003 р. Відомості Верховної Ради Украӥни. 2004. № 15. Ст. 232.

17. Пояснювальна записка до проекту Закону України «Про внесення змін до деяких законів України» (щодо виборчих прав внутрішньо переміщених осіб та інших мобільних всередині країни громадян). URL: http://search.ligazakon.ua/1_doc2.nsf/ link1/GH4TC00A.html.

УДК $340+342.56$

DOI https://doi.org/10.32850/2414-4207.2019-9.06

\title{
ПРАВОВІ ЗАСАДИ РЕАЛІЗАЦІЇ ПРИНЦИПУ ГЛАСНОСТІ І ВІДКРИТОСТІ ДІЯЛЬНОСТІ ОРГАНІВ СУДОВОЇ ВЛАДИ
}

\author{
Коршун Анатолій Олександрович, \\ аспірант \\ (Дніпропетровський державний \\ університет внутрішніх справ, \\ м. Дніпро, Україна)
}

Прозорість та відкритість діяльності судів не є врегульованим питанням. За останні кілька століть, і особливо за останні кілька десятиліть, ця сфера значною мірою змінилася. Стаття присвячена характеристиці правової основи реалізації гласності й відкритості діяльності органів судової влади та забезпеченню міжнародних стандартів відкритості судової системи в Україні. Було наголошено на необхідності забезпечення відкритої діяльності судів через врегулювання відкритого доступу до судових рішень.

Довіра людей до правової системи є вирішальною. Судові спори мають вирішуватися у відкритій судовій системі, доступній для громадян, засобів масової інформації та широкої громадськості. Запропоновано низку рекомендацій щодо подолання виявлених недоліків та підвищення рівня інформаційної відкритості судових органів. Загалом, забезпечення відкритості судової влади сприятиме підвищенню авторитету судових органів та підвищенню рівня довіри до їхньої діяльності в Україні. Найбільш важливим аргументом для забезпечення прозорості судів $є$ право на справедливий суд, оскільки прозорість дозволяє уникнути упередженості, свавілля та незаконності у процесі розгляду справи.

Однак сьогодні необхідність надання публічної інформації не задовольняється простим відкриттям судового розгляду. Судова діяльність еволюціонувала до публічних дебатів, а телевізійні засоби масової інформації служать посередниками для інформування громадськості. Основним елементом процедурної прозорості є публічний судовий розгляд, який вимагається міжнародними документами з прав людини. Основною складовою частиною процедурної прозорості є доступність судових документів, які можуть містити більшість документів, що були подані до суду або створені судом під час процедури розгляду справи. Суди відчувають потребу в активному просуванні інформації про себе та в розробленні політики щодо прозорості та відкритості. Крім того, прозорість і активне надання інформації є ефективними способами запровадження форм соціальної відповідальності без шкоди для незалежності суддів.

Ключові слова: суд, гласність, відкритість, транспарентність, міжнародні стандарти, правові засади, принципи. 


\title{
THE LEGAL BASIS FOR THE IMPLEMENTATION OF PUBLICITY AND OPENNESS OF THE JUDICIAL AUTHORITIES
}

\author{
Korshun Analolii Oleksandrovych, \\ Postgraduate Student \\ (Dnipropetrovsk State University \\ of Internal Affairs, Dnipro, Ukraine)
}

Transparency and openness of the courts is not a settled issue. Over the past few centuries, and especially in the last few decades, this field has changed enormously. The article is devoted to the legal basis for the implementation of the transparency and openness of the judicial authorities and ensuring the international standards of the openness of the judicial system in Ukraine. It was emphasized the need to ensure transparency in the work of the courts by including the regulatory settlement of open access to judicial decisions.

People's confidence in the legal system is crucial. Consequently, disputes must be resolved in an open court system that is accessible to citizens, the media and the general public. It is proposed the recommendations for overcoming the revealed shortages and raising the level of information openness of the judiciary. In general, transparency of the judicial system will enhance the credibility of the judiciary and the level of authority to their activities in Ukraine. The most important argument for the transparency of courts is the right to a fair trial, as transparency ensures that bias, arbitrariness and unlawfulness are avoided in the procedure.

Nowadays, however, the need for public information is not satisfied by mere open trials. Judicial activities have accessed the stage of the public debate, televised mass media serve as intermediaries to inform the public. This affects both the way courts provide information and the level of public expectation. Courts themselves feel the need to actively advance information provision and come up with policies as regards transparency and openness. Furthermore, transparency and active information provision seem to be very effective ways to introduce forms of social accountability without compromising judicial independence.

The main element of procedural transparency is the public trial, which is required by international human rights documents. A basic component of procedural transparency is the accessibility of court documents, which can contain most of the documents that were submitted to the court or created by the court during the procedure.

Key words: court, publicity, openness, transparency, international standards, legal bases, principles.

Доступність, відкритість інформації про діяльність органів судової влади забезпечує обізнаність громадянського суспільства про якість здійснення правосуддя та рівень верховенства права, активізує розвиток громадського контролю, демонструє інформаційну відкритість держави, сприяє запобіганню корупції в судах. В Україні судова влада протягом тривалого часу була інформаційно ізольованою від суспільства. I навіть сьогодні, після завершення активної фази судової реформи, іiї сприймають як найбільш відсторонену від громадян систему, недосяжну для оцінки і критики. Це сприяє недовірі українців до національної судової системи і упередженому ставленню міжнародного співтовариства до правосуддя в Україні.

Попри це, в умовах активізації загальних демократичних тенденцій в Україні варто враховувати важливість гарантування самостійності, незалежності та непідконтрольності судової влади, що постійно знаходиться під тиском низки суб'єктивних і об'єктивних факторів. Все це зумовлює необхідність наукового опрацювання та систематизації правового забезпечення реалізації принципу гласності й відкритості діяльності органів судової влади. 
Різні проблеми забезпечення прозорості в діяльності органів державної влади вивчали відомі науковці: В. Авер' янов, О. Бандурка, Ю. Битяк, В. Гаращук, Т. Коломоєць, Л. Наливайко, Т. Пахомова, А. Пухтецька, В. Серьогін та ін. Окремі аспекти забезпечення відкритості судової влади стали предметом дослідження таких вчених, як: О. Абросімова, А. Безуглов, І. Верба, Л. Воскобітова, В. Городовенко, В. Кондратенко, В. Кряжков, М. Кузьміна, I. Марочкін, А. Марущак, О. Овсяннікова, О. Овчаренко, В. Олійник, М. Погорецький, М. Савенко, Р. Сафаров, Н. Сібільова, О. Харитонов тощо. Не втрачають актуальності наукові розвідки, присвячені правовому забезпеченню принципу гласності і відкритості діяльності органів судової влади в умовах стрімкого розвитку та оновлення законодавства про судоустрій та статус суддів, з урахуванням необхідності реалізації судової реформи.

Метою роботи є дослідження системи правового забезпечення принципу гласності й відкритості діяльності органів судової влади як складового елементу механізму реалізації цього принципу для подальшого приведення системи судової влади України до міжнародних стандартів правосуддя.

В Україні реалізація принципу гласності й відкритості діяльності органів судової влади є чи не обов' язковою умовою функціонування цієї гілки влади. Суспільне переконання в гідності суду можливе лише за тієї умови, щоб кожен крок судової діяльності був відомий суспільству [3, с. 98]. Множинність напрямів, форм і способів забезпечення принципу гласності і відкритості діяльності органів судової влади зумовлює складність та багаторівневість його забезпечення. Пріоритетною в цьому процесі $\epsilon$ саме правова регламентація.

Гласність і відкритість судочинства за своїм змістом є вужчими, ніж транспарентність судової влади та доступність правосуддя [4, с. 40; 5, 87; 6, с. 74]. Крім того, визначаючи правові межі реалізації такого принципу, варто враховувати, що «суд» у вітчизняному законодавстві має три значення: 1) суд як орган державної влади, наділений владними повноваженнями; 2) суд як юридична особа публічного права; 3) суд як орган, що здійснює правосуддя у встановленій законом процесуальній формі [7].

В основу ієрархії правового забезпечення принципу гласності і відкритості діяльності органів судової влади покладено Конституцію України. Її засадничі положення деталізовано в системі законів та підзаконних нормативно-правових актів. Конституційні засади забезпечення діяльності органів судової влади сформовано на основі та з урахуванням міжнародних правових стандартів, що закріплені в ключових міжнародних актах у сфері прав людини, забезпечення демократії та верховенства права. Для комплексного розуміння системи правового забезпечення реалізації досліджуваного принципу є аналіз означених складових елементів.

Основний Закон визнає Україну демократичною державою (ст. 1), що гарантує свободу слова (ст. 34), заборону цензури (ст. 15). У ст. 34 Конституції України гарантується право кожного на інформацію. Це право передбачає і доступ до інформації про діяльність державних органів, а його обмеження можливе лише з передбачених законом підстав, серед яких - підтримка авторитету і неупередженості правосуддя [8]. У ст. 129 Конституції України прямо передбачено принщип гласності судочинства, без деталізації його змісту. Громадяни мають можливість реалізувати право на інформацію, якщо держава створює для цього відповідний механізм та не здійснює активних перешкод.

Правове забезпечення доступності, прозорості, відкритості, гласності правосуддя $\epsilon$ однією з найважливіших гарантій становлення будь-якого демократичного суспільства. Міжнародне співтовариство сформувало систему цивілізаційних стандартів і принципів організації діяльності судової влади, що відповідають інтересам людини, суспільства і держави. 
Міжнародні документи з прав людини гарантують належний відкритий судовий процес (право на справедливий суд), включаючи елемент права на публічний розгляд справи. Крім того, судові слухання були публічними протягом багатьох століть як в Україні, так і у світі [1, с. 150; 2, с. 1921]. Так, у ст. ст. 10, 11 Загальної декларації прав людини від 1948 р. закріплено невід'ємне право кожного на прилюдний розгляд його справи 3 додержанням усіх вимог справедливості незалежним судом. У ст. 19 Декларації передбачено свободу кожного шукати, одержувати і поширювати інформацію та ідеї будь-якими засобами [9]. Міжнародний пакт про громадянські і політичні права від 1966 р. у ст. 14 та Конвенція про захист прав людини і основоположних свобод від 1950 р. у ст. 6 закріплюють аналогічні положення, відповідно до яких кожен має право на справедливий і публічний розгляд справи, а преса і публіка можуть не допускатися на судовий розгляд 3 міркувань моралі, громадського порядку чи державної безпеки, або коли того вимагають інтереси приватного життя сторін [10; 11]. Ці документи також захищають право особи на інформацію, іiі збір та вираження власних поглядів.

У міжнародному законодавстві принцип гласності й відкритості діяльності судової влади органічно корелюється 3 обмеженням поширення конфіденщійної інформації суддями. У п. 15 Основних принципів щодо незалежності правосуддя від 1985 р. зазначено, що судді зобов' язані зберігати професійну таємнищю щодо своєї роботи та конфіденційної інформації, отриманої в ході виконання ними своїх обов'язків, за винятком відкритих судових розглядів [12]. Подібне положення міститься в п. 4.10 Бангалорських принципів поведінки суддів від 2006 р., де зазначено, що конфіденційна інформація, що стала відома судді в силу його посади, не може бути використана ним чи розголошена з будь-якою метою, що не пов'язана з виконанням обов' язків судді [13].

Тривалий час у міжнародній практиці головним елементом принципу гласності й відкритості діяльності органів судової влади був публічний судовий розгляд, який став обов'язковим відповідно до міжнародних документів із прав людини. Основним компонентом процедурної прозорості визнано доступність судових актів, які можуть містити більшість документів, що були подані до суду або створені судом під час процедури. Тенденція демократизації судової влади, рух до ії інформаційної відкритості та орієнтації на суспільні запити з' явились значно пізніше і стали предметом низки рекомендацій Комітету Міністрів Ради Свропи, Генеральної Асамблеї ООН тощо.

На потребі забезпечення гласності й відкритості діяльності судової влади наголошено в Рекомендації CM/Rec (2010) 12 Комітету Міністрів Ради Свропи державам-членам щодо суддів: незалежність, ефективність та обов'язки від 2010 р.: судові провадження та питання, що стосуються здійснення правосуддя, становлять громадський інтерес. Право на отримання інформації щодо судових питань має виконуватися з урахуванням обмежень, установлених з огляду на незалежність судової влади. Схвалюється створення посад речників судів чи відділів 3 питань преси та зв'язків із громадськістю у сфері відповідальності судів або при радах суддів чи інших незалежних органах влади. Суддям слід виявляти стриманість у відносинах зі 3МІ. Судді не можуть ефективно здійснювати правосуддя без довіри громадськості [14]. У Висновку № 7 (2005) Консультативної ради європейських суддів до уваги Комітету Міністрів Ради Європи з питання «Правосуддя та суспільство» зауважено, що адекватна інформація про функції судової влади та ії роль може ефективно сприяти більшому розумінню судів як наріжного каменю демократичних конституційних систем, а також обмежень в їхній діяльності [15]. Інформування громадськості визнано компонентом забезпечення доступності правосуддя. У Рекомендаціях № R (81) 7 Комітету Міністрів Ради Європи державам-членам щодо заходів, які полегшують доступ до пра- 
восуддя, визначено зобов' язання держав-членів ужити належних заходів з інформування громадськості про місцезнаходження і компетенцію судів, порядок звернення до суду, захисту своїх інтересів у судовому порядку. Інформація загального характеру має надаватись або безпосередньо в судах, або в іншій компетентній службі чи органі [16]. Основоположні міжнародні акти у сфері прав людини не тлумачать так широко принцип публічності, що зумовлено різними факторами: раннім етапом їх прийняття, головними цілями та цінностями, які вони охороняють.

Чинна система законів конкретизує та деталізує положення Конституції України і міжнародних актів, тому заслуговує комплексного вивчення.

Закони, що прямо чи опосередковано забезпечують принцип гласності й відкритості діяльності органів судової влади, поділяються на три групи: 1) інформаційне законодавство: Закони України «Про інформацію» від 1992 р., «Про доступ до публічної інформації» від 2011 р., «Про державну таємницю» від 1994 р., «Про захист персональних даних» від 2010 р., «Про Національну програму інформатизації» від 1998 р., «Про друковані засоби масової інформації (пресу) в Україні» від 1992 р., «Про телебачення і радіомовлення» від 1993 р. та ін.; 2) законодавство про судоустрій та статус суддів: Закони України «Про судоустрій та статус суддів» від 2016 р., «Про Конституційний Суд України» від 2017 р., «Про Вищий антикорупційний суд» від 2018 р.; «Про доступ до судових рішень» від 2005 р., «Про Вищу раду правосуддя» від 2016 р.; «Про відновлення довіри до судової влади в Україні» від 2014 р. тощо; 3) проиесуальне законодавство: Кримінальний процесуальний кодекс України від 2012 р., Цивільний процесуальний кодекс України від 2004 р., Кодекс адміністративного судочинства України від 2005 р., Господарський процесуальний кодекс України від 1991 р.

Окремо слід відзначити антикорупційне законодавство та підгрупи законів, що встановлюють основи проведення громадського контролю, правовий статус інститутів громадянського суспільства тощо. Детальної уваги заслуговують деякі закони із зазначеного переліку.

Основою інформаційної відкритості органів державної влади є інформаційне законодавство, що гарантує право на інформацію, відкритість, доступність інформації, свободу обміну інформацією (ст. 2 Закону України «Про інформацію» від 1992 р.). Серед напрямів державної інформаційної політики визначено забезпечення відкритості та прозорості діяльності суб'єктів владних повноважень (ст. 3 Закону України «Про інформацію» від 1992 р.). Публічна інформація, що була отримана або створена в процесі виконання суб'єктами владних повноважень своїх обов'язків або яка знаходиться у володінні суб'єктів владних повноважень, є відкритою (ст. 1 Закону України «Про доступ до публічної інформації» від 2011 р.). Розпорядниками публічної інформації визнаються всі без винятку органи державної влади.

Але якщо публічна інформація отримана чи створена судом під час виконання ним функцій органу державної влади або в процесі діяльності як юридичної особи, тобто не під час здійснення функції правосуддя, то така інформація підпадає під дію Закону України «Про доступ до публічної інформації» від 2011 р. Натомість на інформацію, отриману чи створену судом як судовим органом, тобто органом правосуддя в процесі судочинства, його дія не поширюється [7]. Для подолання вказаної прогалини та з метою забезпечення відкритості діяльності судів загальної юрисдикції було прийнято Закон України «Про доступ до судових рішень» від 2005 р.

Відповідно до ст. 2 зазначеного закону всі судові рішення загальних судів є відкритими та підлягають оприлюдненню в електронній формі. Якщо судовий розгляд відбувався у закритому судовому засіданні, судове рішення оприлюднюється з виключенням закритої інформації [17]. Законом започатковано створення Сдиного 
державного реєстру судових рішень - електронної платформи для опублікування судових рішень, судових наказів, постанов, вироків, ухвал, ухвалених судами загальної юрисдикції.

Щодо рішень Конституційного Суду України обов' язковість їх опублікування встановлена у ст. 94 Закону України «Про Конституційний Суд України» від 2017 р., де зазначено, що оприлюдненню підлягають усі акти за результатами конституційного провадження на офіційному веб-сайті суду або в залі засідань суду. Опублікування судових актів здійснюється у «Віснику Конституційного Суду України» та інших офіційних друкованих виданнях України [18]. Виняток становлять рішення, що містять державну таємницю.

У ст. 11 Закону України «Про судоустрій і статус суддів» від 2016 р. визначено сутність та особливості забезпечення гласності й відкритості судового процесу в тому розумінні, що передбачене міжнародними актами у сфері прав людини. Основними його принципами є: 1) відкритість судових рішень, засідань та інформація щодо справ; 2) заборона обмеження права на отримання інформації про результати розгляду справи; 3) відкритість інформації про рух справи; 4) доступ будь-якої особи до відкритого судового засідання; 5) дозвіл проводити в залі судового засідання фотозйомку, відео- та аудіозапис без отримання окремого дозволу суду; 6) можливість трансляції судового засідання; 7) обов' язкова трансляція в мережі Інтернет судового засідання, що здійснюється в режимі відеоконференції; 8) обов'язкова фіксація перебігу судового процесу технічними засобами; 9) проведення засідань у залі засідань, яка придатна для розміщення громадян [19]. Схожий, але дещо обмежений підхід закріплено в ст. 6 Закону України «Про Конституційний Суд України» від 2017 р. Відкритість діяльності цього суду ототожнено з відкритим розглядом справ на пленарних засіданнях Великої палати, Сенату Конституційного Суду, за винятком закритої частини цих засідань. Бажаючі бути присутніми на відкритій частині пленарного засідання Великої палати, Сенату можуть вільно скористатися таким правом, а представники 3МI можуть здійснювати відео- та фотофіксацію, вести аудіозапис [18]. Принагідно зазначимо, що в Законі України «Про Вищий антикорупщійний суд» від 2018 р. взагалі не зазначені принципи судочинства, в тому числі відсутні положення про принцип гласності й відкритості діяльності цього суду. Враховуючи, що правову основу діяльності Вищого антикорупщійного суду становить Закон України «Про судоустрій і статус суддів» від 2016 р., зазначені в ст. 11 вимоги поширюються і на новостворений антикорупційний суд.

Складниками забезпечення гласності й відкритості діяльності судової влади $\epsilon$ антикорупційні запобіжні заходи у сфері судової влади, а саме: моніторинг способу життя судді, електронне декларування доходів судді, декларування родинних зв'язків та декларування доброчесності судді. Результатом цих заходів $є$ оприлюднення інформації про окремі аспекти життя судді, що дають змогу контролювати дотримання антикорупційного законодавства.

Важливе значення має процесуальне законодавство, що встановлює процедурні аспекти забезпечення гласності й відкритості судового розгляду (ст. 27 Кримінально процесуального кодексу України від 2012 р.; ст. ст. 7, 8 Цивільного процесуального кодексу України від 2004 р.; ст. ст. 10, 11 Кодексу адміністративного судочинства України від 2005 р.; ст. 8 Господарського процесуального кодексу України від 1991 р.). У всіх зазначених документах цей принцип визначено однаково і у відповідності до Закону України «Про судоустрій і статус суддів» від 2016 р.

Правове забезпечення принципу гласності й відкритості діяльності органів судової влади конкретизується в системі підзаконних нормативно-правових актів, що 
деталізують положення чинного законодавства. Суб'єктами прийняття таких актів виступають переважно державні органи в системі правосуддя, органи суддівського самоврядування.

Провідне місце в системі підзаконних нормативно-правових актів належить Кодексу суддівської етики від 2013 р. У ст. 11 Кодексу встановлено, що суддя повинен проявляти повагу до права на інформацію про судовий розгляд та не допускати порушення принципу гласності процесу. Суддя надає 3МІ можливість отримувати інформацію. У ст. 12 визначено обмеження, відповідно до яких суддя не може робити публічних заяв, коментувати у ЗМІ справи, які перебувають у провадженні суду, та піддавати сумніву судові рішення, що набрали законної сили [20]. Цей документ є чи не єдиним підзаконним нормативно-правовими актом, що прямо вказує на необхідність забезпечення інформаційної відкритості судової влади.

Майже всі інші підзаконні нормативно-правові акти присвячені технологічним, організаційним вимогам до висвітлення інформації про діяльність судової влади. Основними з них є: Регламент Конституційного Суду України, затверджений Постановою КСУ від 2018 р.; Наказ Державної судової адміністрації України від 2014 р. «Про організаційне забезпечення функціонування веб-порталу «Судова влада України»; Рішення Вищої ради правосуддя від 2018 р. «Про затвердження Порядку ведення Єдиного державного реєстру судових рішень» та ін.

Натепер у судах діють положення про суддів 3 питань зв'язків 3 громадськістю. Вони приймаються на виконання Рішення Ради суддів України від 2015 р. «Про схвалення рекомендацій міжнародної конференції «Зміцнення довіри до судової гілки влади через покращення комунікації», що визнає розвиток та вдосконалення комунікації судів із громадськістю одним із пріоритетних напрямків роботи кожного суду. Судді-спікери, пройшовши підготовку в Національній школі суддів України, стають не просто посередниками між ЗМІ та судом, а професійно реалізують комунікативну політику суду, активно впливають на відновлення довіри до судової влади.

На сьогодні в Україні не напрацьований досвід комунікаційної та інформаційної відкритості суду. Цей процес розпочався з проведення судової реформи під впливом міжнародного співтовариства і проходить стадію формування. Довіра до судової влади в Україні залишається досить низькою, але спостерігається позитивна динаміка. Це свідчить про ефективність обраного курсу на забезпечення реалізації принципу гласності й відкритості діяльності судової влади.

Підводячи підсумки проведеного аналізу, варто зазначити:

1. В основу правового забезпечення принципу гласності й відкритості діяльності органів судової влади покладено Конституцію України. Ії̈ положення деталізовано в системі законів, які можна поділити на три групи: інформаційне законодавство; законодавство про судоустрій та статус суддів; процесуальне законодавство. Опосередковано забезпечує реалізацію досліджуваного принципу антикорупційне законодавство та підгрупи законів, що встановлюють основи проведення громадського контролю, правовий статус інститутів громадянського суспільства тощо. Правове забезпечення принципу гласності й відкритості діяльності органів судової влади конкретизується в системі підзаконних нормативно-правових актів. Суб'єктами прийняття таких актів виступають переважно державні органи в системі правосуддя, органи суддівського самоврядування.

2. Національні правові засади забезпечення діяльності судової влади сформовано на основі та з урахуванням міжнародних правових стандартів, що закріплені в міжнародних актах у сфері прав людини, забезпечення демократії та верховенства права. Тривалий час у міжнародній практиці головним принципом діяльності судової влади 
був публічний судовий розгляд. Тенденція ототожнення відкритості суду і публічності судового процесу призвела до хибного розуміння змісту інформаційної відкритості судової влади як однієї з гілок державної влади. Принцип гласності й відкритості діяльності органів судової влади є ширшим, ніж публічність судового процесу. Вимога забезпечення гласності й відкритості діяльності судової влади є похідною від права людини на інформацію і принципу доступності правосуддя, що у свою чергу $\epsilon$ гарантіями дотримання прав людини.

3. Гласність і відкритість діяльності судових органів включає інформування громадськості про діяльність судової системи комплексно. Вітчизняні суди ініціативно висвітлюють актуальну інформацію про себе на веб-сайті судової влади, взаємодіють із громадськістю через суддів-спікерів, проводять дні відкритих дверей тощо. Важливою умовою демократичних перетворень $є$ уникнення формалізму та надання необ'єктивної, викривленої інформації про діяльність судової влади.

\section{Список використаних джерел:}

1. Voermans W. Judicial transparency furthering public accountability for new judiciaries. Utrecht Law Review. 2007. Volume 3. Issue 1. P. 148-159. URL: http:// www.utrechtlawreview.org/

2. Youm K.H. Cameras in the Courtroom in the XIX Century: The U.S. Supreme Court Learning From Abroad? BYU Law Review. 2012. № 6. P. 1989-2032.

3. Фойницкий И.Я. Курс уголовного судопроизводства : в 2 т. Санкт-Петербург, 1996. Т. 1. С. 98.

4. Городовенко В.В. Принцип гласності і відкритості у вітчизняному судочинстві: проблеми реалізації. Вісник Верховного Суду Украӥни. 2011. № 9 (133). С. 38-43.

5. Верба I.О. Право на доступ до правосуддя та його юридичне забезпечення: загальноправова характеристика : дис. ... кан. юрид. наук. Запоріжжя. 2016. 210 с.

6. Овчаренко О.М. Доступність правосуддя та гарантії його реалізації : монографія. Харків, 2008. С. 74.

7. Савенко М.Д. Науковий висновок Науково-консультативній раді при Вищому адміністративному суді України. URL: http://www.vasu.gov.ua/userfiles/file/NKR/ Nauk_visnovki/Publichna_informacija

8. Конституція України від 28.06.1996. Відомості Верховної Ради України. 1996. № 30. СТ. 141.

9. Загальна декларація прав людини : Міжнародний документ від 10.12.1948 р. Офріиійний вісник України. 2008. № 93. Ст. 3103.

10. Міжнародний пакт про громадянські і політичні права : Міжнародний документ від 16.12.1966 p. URL: https:/ / zakon.rada.gov.ua/laws/show/995_043

11. Конвенція про захист прав людини і основоположних свобод : Міжнародний від 04.11.1950 р. Урядовий кур'єр. 2010. № 215.

12. Основні принципи щодо незалежності правосуддя : Резолюція 40/32, 40/146 Генеральної Асамблеї ООН від 29.11 та 13.12.1985 p. URL: https:/ / court.gov.ua/ userfiles/01.pdf

13. Бангалорські принципи поведінки суддів : Резолюція 2006/23 Економічної і Соціальної Ради ООН від 27.07.2006 р. URL: https:/ / court.gov.ua/ userfiles/02.pdf

14. Рекомендація CM/Rec (2010) 12 Комітету Міністрів Ради Свропи державам-членам щодо суддів: незалежність, ефективність та обов'язки від 17.11. 2010 p. URL: https://court.gov.ua/inshe/mss

15. Висновок № 7 (2005) Консультативної ради європейських суддів до уваги Комітету Міністрів Ради Свропи з питання «Правосуддя та суспільство» від 23-25.11.2005 р. URL: https:/ / court.gov.ua/userfiles/visn_7_2005.pdf 
16. Рекомендація № R (81) 7 Комітету Міністрів Ради Свропи державам-членам щодо заходів, що полегшують доступ до правосуддя від 14.05.1981 p. URL: https://court.gov.ua/userfiles/08.pdf

17. Про доступ до судових рішень : Закон України від 22.12.2005 р. Відомості Верховної Ради України. 2006. № 15. Ст. 128.

18. Про Конституційний Суд України : Закон України від 13.07.2017 р. Відомості Верховної Ради України. 2017. № 35. Ст. 376.

19. Про судоустрій та статус суддів : Закон України від 02.06.2016 р. Bidомості Верховної Ради Украӥни. 2016. № 31. Ст. 545.

20. Рішення XI 3'їзду Суддів України від 22.02.2013 р. «Про затвердження Кодексу суддівської етики». Вісник Верховного суду України. 2013. № 3. Ст. 27.

\title{
УДК 340.132
}

DOI https:/ / doi.org/10.32850/2414-4207.2019-9.07

\section{ОЗНАКИ ПРАВОТВОРЧОСТІ ВЕРХОВНОГО СУДУ ТА КОНСТИТУЦЙНОГО СУДУ УКРАЇНИ ЯК САМОСТІЙНИХ ЮРИДИЧНИХ КАТЕГОРІЙ}

\author{
Кравчук Катерина Геннадіївна, \\ аспірантка юридичного факультету \\ (Київський національний університет \\ імені Тараса Шевченка, \\ м. Київ, Україна)
}

Важливою складовою частиною дослідження теоретико-правових та практичних аспектів співвідношення правотворчості Верховного Суду та Конституційного Суду України є їх категоріальний вимір, що заснований на екстракщії властивостей досліджуваного явища та особливостях його прояву в діяльності зазначених суб'єктів. Оскільки в юридичній науці сьогодні представлені поодинокі погляди вчених, що стосуються поняття правотворчості Верховного Суду та Конституційного Суду Україні, саме категоріальний вимір досліджуваних явищ потенщійно спроможний охарактеризувати їхні властивості, здійснити їх порівняння та обгрунтувати положення, котрі стосуватимуться їх співвідношення.

У роботі здійснено аналіз поглядів учених, які стосуються ознак та визначень понять «правотворчість Верховного Суду» і «правотворчість Конституційного Суду України». Автором з'ясовано стан доктринальної розробки правотворчості Верховного Суду та Конституційного Суду України як самостійних юридичних категорій. Виокремлено спільні, схожі, відмінні та протилежні ознаки правотворчості Верховного Суду та правотворчості Конституційного Суду України, надано їх характеристику. Обгрунтовано самостійність понять «правотворчість Верховного Суду» та «правотворчість Конституційного Суду України» в системі понятійно-категоріального апарату юридичної науки.

Підсумовано, що з метою уточнення визначень таких понять, як «правотворчість Верховного Суду» та «правотворчість Конституційного Суду України», в основу такого уточнення варто покласти виокремлені спільні, схожі, відмінні та протилежні ознаки. Це дозволить відобразити їх: а) тотожність як правовий феномен; б) подібність як особливі різновиди практичної діяльності у сфері права; в) автентичність як явища, наділені виключними ознаками, що притаманні правотворчості Верховного Суду та відсутні в правотворчості Конституційного Суду України, і навпаки; г) про- 